\title{
Fruit flies (Diptera, Tephritidae) and their parasitoids on cultivated and wild hosts in the Cerrado-Pantanal ecotone in Mato Grosso do Sul, Brazil
}

\author{
Tiago Ledesma Taira ${ }^{1}$, Alfredo Raúl Abot ${ }^{1}$, José Nicácioº ${ }^{2}$ Manoel Araécio Uchôa ${ }^{2}$, \\ Sérgio Roberto Rodrigues ${ }^{1} \&$ Jorge Anderson Guimarães ${ }^{3}$
}

\begin{abstract}
'Universidade Estadual de Mato Grosso do Sul, Rodovia Aquidauana-CERA, km 12, 79200-000 Aquidauana-MS, Brasil. tiago_taira@hotmail.com ${ }^{2}$ Universidade Federal da Grande Dourados, Av. Guaicurus km 12, 79804-970 Dourados-MS, Brasil.

${ }^{3}$ Embrapa Hortaliças, Rodovia Brasília/Anápolis BR 060, Km 09, 70359-970 Gama-DF, Brasil.
\end{abstract}

\begin{abstract}
Fruit flies (Diptera, Tephritidae) and their parasitoids on cultivated and wild hosts in the Cerrado-Pantanal ecotone in Mato Grosso do Sul, Brazil. Information on frugivorous flies in cultivated or wild host plants and their parasitoids in the Cerrado-Pantanal ecotone in Aquidauana, Mato Grosso do Sul is presented and discussed. Fruit fly samples were collected weekly in specific fruit trees, and McPhail ${ }^{\circledR}$ traps were installed in the same trees for a period of two years. The fruit flies infested ripe and unripe fruits of Averrhoa carambola L., Schoepfia sp., Psidium guajava L. and Pouteria torta (Mart.) Radlk and mature fruits of Anacardium occidentale L. and Inga laurina (Sw.) Willd. Nineteen fruit fly species were obtained with the combination of sampling methods (collecting fruits and trapping), nine of them obtained with both methods, five found only in fruits and five only in traps. This is the first record of Anastrepha striata Schiner in a species of Sapotaceae, as well as for A. castanea Norrbom and A. daciformes Bezzi in Schoepfia sp. (Olacaceae), and for A. distincta Greene in fruits of P. guajava in the state of Mato Grosso do Sul. Fruit collections simultaneously associated with capture of fruit flies by McPhail traps in the same host plants are essential to understand the diversity of fruit flies and their relationship with hosts and parasitoids. Species of Braconidae and Pteromalidae were recovered, where Doryctobracon areolatus (Szépligeti) was the most abundant parasitoid in larvae of tephritids infesting both cultivated and wild host fruits.
\end{abstract}

KEYWORDS. Insecta; Mediterranean fruit fly; quarantine pests; Tephritoidea.

Tropical fruits are important for developing regions due to their economic and nutritional characteristics. About $90 \%$ of these fruits produced worldwide are consumed in the countries where they are produced, and the rest is exported in natura or processed. The value of tropical fruit production was estimated at 43.7 billion dollars in 2008 (FAO 2009). Brazil is the third largest producer of fruits after China and India, with annual production of about 43 million tons (INCT 2009).

Frugivorous fruit flies, especially species of Tephritidae, which in the larval stage consume fruit pulp from different botanical families (Zucchi 2000a; Gonçalves et al. 2006; Garcia \& Norrbom 2011; Ronchi-Teles et al. 2011), have been a major problem for world fruit production. Although known as fruit flies, some species of larval Tephritoidea can feed on flower buds, flowers, buds, leaves, seeds and roots (Evstigneev 2011; Khaghaninia et al. 2011; Sabedot-Bordin et al. 2011; Uchôa 2012).

The genera of greatest importance to Brazil are Anastrepha Schiner, 1868, Ceratitis Macleay, 1829, Bactrocera Macquart, 1835 and Rhagoletis Loew, 1862, with an emphasis on the first two due to the large number of hosts which they utilize (Zucchi 2000b, 2007). In Mato Grosso do Sul, the occurrence of Ceratitis capitata (Wiedemann, 1824) has been reported along with nearly 30 species of Anastrepha (Uchôa-Fernandes et al. 2002, 2003a; Rodrigues et al. 2006; Canesin \& UchôaFernandes et al. 2007; Uchôa \& Nicácio 2010).
Losses to Brazilian fruticulture related to these pests vary between 120 and 200 million dollars annually, due to high cost of control (Felix et al. 2009) and phytosanitary barriers of importing countries (Paranhos et al. 2007). Knowledge of the relationship between frugivorous tephritids and their hosts is critical for the control of pest species (Nicácio \& Uchôa 2011). However, it is important to know the phenology of these fruit trees, mainly native and/or non-cultivated species, since tephritid pests may use them to maintain their populations during the offseason of planted fruit crops.

Several studies have been conducted with Tephritidae using traps, especially those of the model McPhail ${ }^{\circledR}$, used worldwide for monitoring and/or control of these insects (Rousse et al. 2005; Canesin \& Uchôa-Fernandes et al. 2007; Jemâa et al. 2010). However, when seeking to understand the diversity of economically important fruit flies it is necessary to conduct intensive analyses in the fruits themselves (Zucchi 2000b), since not only is the association between the fly species with the host plant verified, but there is also identification of its parasitoids.

The objective of this study was to understand the interaction between fruit flies (Tephritidae) and their parasitoids in cultivated and wild hosts, based on survey of plant reproductive structures and use of McPhail ${ }^{\circledR}$ traps, in an area of the Cerrado-Pantanal ecotone of Mato Grosso do Sul, Brazil. 


\section{MATERIAL AND METHODS}

The study was conducted on the campus of the State University of Mato Grosso do Sul (UEMS) in Aquidauana and in an adjacent area during two years, from June 27, 2009 to June 26, 2011. The climate, according to the Köppen classification, is type Aw (Tropical warm - wet) with rainy summer and dry winter, with annual precipitation of 1,250 to $1,500 \mathrm{~mm}$ and an average temperature of $26^{\circ} \mathrm{C}$. The region is comprised of native vegetation, large areas of pasture (cultivated grasses), small domestic orchards and an experimental area of fruit and annual crops of the UEMS, where guava, mango, banana and coconut are grown along with various plant species.

McPhail ${ }^{\circledR}$ traps, baited with $300 \mathrm{ml}$ of $5 \%$ hydrolzed corn protein (Uchôa-Fernandes et al. 2003b), were used in association with collecting of plant reproductive structures from wild and cultivated fruit species (Table I). The bait was renewed weekly when the captured flies were also collected, which were placed in labeled vials containing $80 \%$ ethanol. Each fruit species was represented by one plant and in each plant one trap was installed at $1.7 \mathrm{~m}$ above the ground. The reproductive structures were collected concurrently with the collection of material from the traps. Phenological phases were classified as bud, flower, unripe fruit and ripe fruit. The quantity of reproductive structures was dependent on the availability in the field (Table II). Ripe fruits were randomly collected from the plant in which the trap was installed, and in previous stages fruits were also collected from plants of the same species surrounding the plant in which the trap was installed.

The reproductive structures were placed on wooden pallets with a sombrite screen, with $1 \mathrm{~cm}^{2}$ openings. The pallets were placed inside black plastic containers measuring $57 \times 37 \times 12 \mathrm{~cm}$, containing water at a depth of $2 \mathrm{~cm}$ to retain third instar larvae in the case they abandoned the fruits (Uchôa-Fernandes \& Zucchi 1999).

The recipients were monitored daily between $7 \mathrm{~h} 00$ and $17 \mathrm{~h} 00$ to avoid death of the larvae by drowning. Larvae were transferred to transparent plastic vials $(200 \mathrm{~mL})$, one used as a base and the other as a lid, secured with adhesive tape. A 4 $\mathrm{cm}$ layer of sterilized sand moistened with distilled water was placed on the base. The recovered adults and their parasitoids were sacrificed 24 hours after emergence and were
Table II. Quantity of reproductive structures and fruit mass from selected fruit plant species collected in the Cerrado-Pantanal ecotone, Aquidauana, Mato Grosso do Sul, Brazil (June 2009 to June 2011).

\begin{tabular}{|c|c|c|c|c|c|c|}
\hline \multirow{3}{*}{ Host } & \multicolumn{6}{|c|}{ Phenological stage } \\
\hline & \multirow[t]{2}{*}{ Bud } & \multirow[t]{2}{*}{ Flower } & \multicolumn{2}{|c|}{ Unripe fruit } & \multicolumn{2}{|c|}{ Ripe fruit } \\
\hline & & & Quantity & $\begin{array}{c}\text { Mass } \\
(\mathrm{kg})\end{array}$ & Quantity & $\begin{array}{c}\text { Mass } \\
(\mathrm{kg})\end{array}$ \\
\hline Anacardium occidentale & 3 & 5 & 15 & 1.32 & 27 & 10.82 \\
\hline Annona muricata & - & 28 & 67 & 15.80 & 6 & 2.20 \\
\hline Averrhoa carambola & 1 & 7 & 17 & 2.29 & 68 & 39.30 \\
\hline Citrus sinensis & - & - & 44 & 21.06 & 34 & 29.47 \\
\hline Psidium guajava & - & - & 45 & 12.89 & 59 & 112.17 \\
\hline Buchenavia tomentosa & 3 & 4 & 8 & 0.94 & 11 & 1.86 \\
\hline Dipteryx alata & 8 & 3 & 68 & 10.97 & 5 & 0.95 \\
\hline Inga laurina & 6 & 3 & 46 & 2.33 & 22 & 1.93 \\
\hline Pouteria torta & 12 & 3 & 23 & 3.06 & 9 & 12.30 \\
\hline Schoepfia sp. & - & 5 & 3 & 0.49 & 10 & 3.14 \\
\hline
\end{tabular}

stored in $80 \%$ ethanol for later identification. The Tephritidae specimens were identified by Prof. Dr. Manoel A. Uchôa (Federal University of Grande Dorados (UFGD), Dourados, Mato Grosso do Sul, Brazil) and the parasitoids by Dr. Jorge Anderson Guimarães (Embrapa Hortaliças, Brasília, Distrito Federal, Brazil). Some Tephritidae specimens are deposited in the entomology collection of the UEMS and at the Museum of Biodiversity, School of Biological and Environmental Sciences of the UFGD; the parasitoid specimens are stored at Embrapa Hortaliças.

The absolute and relative abundances of Tephritidae species were expressed in relation to total females recovered, while the absolute abundance of parasitoids was in relation to the total number of individuals. For analysis of the population fluctuation of frugivorous fly species and the quantity (weight) of fruit, the data obtained per week was used, i.e., the means from 4-5 repetitions per month. The parasitism percentage was calculated according to the equation: [number of parasitoids recovered*100/Number of larvae $\left(3^{\text {rd }}\right.$ instar) of Tephritidae].

\section{RESULTS}

Of the reproductive structures from the fruit plants assessed, only the fruits themselves were infested by tephritids. Of these, 6,746 larvae were obtained in fruits of Anacardium

Table I. Fruit plants sampled and their locations in the Cerrado-Pantanal ecotone, Aquidauana, Mato Grosso do Sul, Brazil (June 2009 to June 2011).

\begin{tabular}{|c|c|c|c|c|c|c|}
\hline Hosts & Family & Species & Common name & Origin & Geographical Location & Elevation \\
\hline \multirow[t]{5}{*}{ Cultivated } & Anacardiaceae & Anacardium occidentale L., 1753 & Cashew & Native & $20^{\circ} 26^{\prime} 14^{\prime \prime} \mathrm{S}, 55^{\circ} 39^{\prime} 41^{\prime \prime} \mathrm{W}$ & $201 \mathrm{~m}$ \\
\hline & Annonaceae & Annona muricata L., 1753 & Soursop & Exotic & $20^{\circ} 29^{\prime} 56^{\prime \prime} \mathrm{S}, 55^{\circ} 37^{\prime} 05^{\prime \prime} \mathrm{W}$ & $162 \mathrm{~m}$ \\
\hline & Oxalidaceae & Averrhoa carambola L., 1753 & Starfruit & Exotic & $20^{\circ} 28^{\prime} 59^{\prime \prime} \mathrm{S}, 55^{\circ} 38^{\prime} 05^{\prime \prime} \mathrm{W}$ & $181 \mathrm{~m}$ \\
\hline & Rutaceae & Citrus sinensis (L.) Osbeck, 1765 & Orange & Exotic & $20^{\circ} 29^{\prime} 47^{\prime \prime} \mathrm{S}, 55^{\circ} 36^{\prime} 41^{\prime \prime} \mathrm{W}$ & $153 \mathrm{~m}$ \\
\hline & Myrtaceae & Psidium guajava L., 1753 & Guava & Native & $20^{\circ} 26^{\prime} 27^{\prime \prime} \mathrm{S}, 55^{\circ} 39^{\prime} 49^{\prime \prime} \mathrm{W}$ & $195 \mathrm{~m}$ \\
\hline \multirow[t]{5}{*}{ Non-cultivated } & Combretaceae & Buchenavia tomentosa Eichler, 1866 & Tarumarana & Native & $20^{\circ} 26^{\prime} 12^{\prime \prime} \mathrm{S}, 55^{\circ} 39^{\prime} 22^{\prime \prime} \mathrm{W}$ & $180 \mathrm{~m}$ \\
\hline & Fabaceae & Dipteryx alata Vogel, 1837 & Cumbaru & Native & $20^{\circ} 27^{\prime} 32^{\prime \prime} \mathrm{S}, 55^{\circ} 39^{\prime} 48^{\prime \prime} \mathrm{W}$ & $208 \mathrm{~m}$ \\
\hline & Fabaceae & Inga laurina (Sw.) Willdenow, 1806 & Ingá & Native & $20^{\circ} 26^{\prime} 12^{\prime \prime} \mathrm{S}, 55^{\circ} 39^{\prime} 35^{\prime \prime} \mathrm{W}$ & $209 \mathrm{~m}$ \\
\hline & Sapotaceae & Pouteria torta (Mart.) Radlk, 1882 & Guapeva & Native & $20^{\circ} 26^{\prime} 04^{\prime \prime} \mathrm{S}, 55^{\circ} 39^{\prime} 31^{\prime \prime} \mathrm{W}$ & $227 \mathrm{~m}$ \\
\hline & Schoepfiaceae & Schoepfia sp. & Chora-menina & Native & $20^{\circ} 26^{\prime} 08^{\prime \prime} \mathrm{S}, 55^{\circ} 39^{\prime} 33^{\prime \prime} \mathrm{W}$ & $216 \mathrm{~m}$ \\
\hline
\end{tabular}


occidentale L., Averrhoa carambola L., Inga laurina (Sw.) Willd., Pouteria torta (Mart.) Radlk, Psidium guajava L. and Shoepfia sp., which resulted in 4,424 adults (67.74\% viability), with a sex ratio of $1: 1$. The sum of larvae in fruits of $A$. carambola $(2,372), P$. guajava $(2,711)$ and $P$. torta $(1,635)$ accounted for $99.58 \%$ of the total (Table III).

Larvae were recovered in unripe and ripe fruits of $A$. carambola, P. torta, P. guajava and Shoepfia sp. and ripe fruits of $A$. occidentale and de I. laurina. Of the total number of larvae in $A$. carambola fruits, $98.61 \%$ were obtained from ripe fruit and they presented viability of $71.13 \%$, where in unripe fruits larval viability was $62.50 \%$. Among larvae collected from $P$. guajava fruits, $86.28 \%$ were obtained from ripe fruits with viability of $60.00 \%$, while those from unripe fruit presented viability of $76.00 \%$. In fruits of $P$. torta, $91.38 \%$ of larvae were obtained from ripe fruits with viability of $73.57 \%$, lower than the viability of larvae obtained from unripe fruits (Table III).

Fruits of $P$. guajava, A carambola and $P$. torta presented the highest rates of infestation with $20.48,56.24$ and 97.27 larvae $\mathrm{kg}^{-1}$, respectively. Contrarily, the fruits of $A$. occidentale, I. laurina and Shoepfia sp. which had the lowest number of larvae showed infestations of $0.16,2.11$ and 4.68 larvae $\mathrm{kg}^{-1}$, respectively.

In all the traps associated with fruit trees at least one frugivorous tephritid specimen was captured (Table III). Of the 378 flies captured with this method, 113 were females and 265 males, resulting in a 1:2 sex ratio (Q: $\left.\sigma^{\prime}\right)$. Of the total number of flies captured, $0.79 \%$ were acquired from traps installed in A. occidentale; $5.82 \%$ from Annona muricata L.; $14.81 \%$ from $A$. carambola; $2.65 \%$ from Buchenavia tomentosa Eichler; 0.26\% from Citrus sinensis (L.) Osbeck;
$3.97 \%$ from Dipterix alata Vogel; 2.38\% from I. laurina; $9.26 \%$ from P. torta; $58.73 \%$ from P. guajava and $1.32 \%$ from Shoepfia sp. (Table III).

Nineteen fruit fly species were obtained with the combination of sampling methods (collecting fruits and trapping), nine of them obtained with both methods, five found only in fruits and five only in traps (Table IV). In relation to the fruit samples, $A$. carambola presented the greatest number of positive samples (818), followed by $P$. guajava (767) and $P$. torta (599). These same fruits showed a larger number of associated fly species, where eight species were found in P. guajava, five in $P$. torta and four in A. carambola (Table IV).

The increased number and diversity of fruit fly species in the collecting method using traps were confirmed in those installed in P. guajava (45.13\% of the species; 6 species), followed by those installed in A. carambola $(22.12 \%$ of the species; 4 species) and P. torta (12.39\% of the species; 5 species) (Table IV).

Of the 14 species associated with fruits, five infested both unripe and ripe fruits, seven occurred only in ripe fruits and two were found only in unripe fruits (Table V). More than $90 \%$ of fruit flies from fruits of $A$. carambola, I. laurina, $P$. torta and $P$. guajava were acquired from larvae infesting ripe fruits. In Shoepfia sp., 75\% of the flies were also associated with this maturation phase (Table V).

Anastrepha obliqua occurred in July and August of 2009, during seven months of 2010 and six months of 2011 in $A$. carambola, presenting three population peaks (Fig. 1). This species also occurred in P. guajava from November 2009 to February 2010 and in April 2010. Ceratitis capitata infested A. carambola fruits during six months of 2010 and five of 2011, with the highest average number of larvae in July 2010

Table III. Sampling methods of larvae and adults of Tephritidae associated with cultivated and wild fruit plants in the Cerrado-Pantanal ecotone, Aquidauana, Mato Grosso do Sul, Brazil (June 2009 to June 2011).

\begin{tabular}{|c|c|c|c|c|c|c|}
\hline Host & Sampling method & Maturation state of the fruit & Number of Larvae & Number of females & Number of males & Viability (\%) \\
\hline \multirow[t]{2}{*}{ Anacardium occidentale } & Fruit & Ripe & 2 & - & - & 0 \\
\hline & Trap & - & - & 1 & 2 & - \\
\hline Annona muricata & Trap & - & - & 10 & 12 & - \\
\hline \multirow[t]{3}{*}{ Averrhoa carambola } & Fruit & Unripe & 33 & 13 & 7 & 62.50 \\
\hline & & Ripe & 2,339 & 805 & 794 & 71.13 \\
\hline & Trap & - & - & 25 & 31 & - \\
\hline Buchenavia tomentosa & Trap & - & - & 3 & 7 & - \\
\hline Citrus sinensis & Trap & - & - & 0 & 1 & - \\
\hline Dipteryx alata & Trap & - & - & 2 & 13 & - \\
\hline \multirow[t]{2}{*}{ Inga laurina } & Fruit & Ripe & 9 & 2 & 7 & 100.00 \\
\hline & Trap & - & - & 5 & 4 & - \\
\hline \multirow[t]{3}{*}{ Pouteria torta } & Fruit & Unripe & 141 & 59 & 55 & 80.85 \\
\hline & & Ripe & 1,494 & 540 & 543 & 73.57 \\
\hline & Trap & - & - & 14 & 21 & - \\
\hline \multirow[t]{3}{*}{ Psidium guajava } & Fruit & Unripe & 150 & 64 & 50 & 76.00 \\
\hline & & Ripe & 2,561 & 703 & 773 & 60.00 \\
\hline & Trap & - & - & 51 & 171 & - \\
\hline \multirow[t]{3}{*}{ Schoepfia sp. } & Fruit & Unripe & 4 & 1 & 2 & 75.00 \\
\hline & & Ripe & 13 & 3 & 3 & 46.15 \\
\hline & Trap & - & - & 2 & 3 & - \\
\hline \multirow[t]{2}{*}{ Total } & Fruit & - & 6,746 & 2190 & 2234 & 67.74 \\
\hline & Trap & - & - & 113 & 265 & - \\
\hline
\end{tabular}




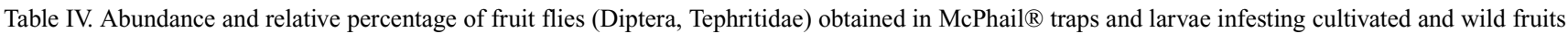
in the Cerrado-Pantanal ecotone, Aquidauana, Mato Grosso do Sul, Brazil (June 2009 to June 2011).

\begin{tabular}{|c|c|c|c|c|c|c|c|c|c|c|c|c|c|c|c|c|c|c|c|c|}
\hline \multirow{3}{*}{ Tribe/Species } & \multicolumn{18}{|c|}{ Hosts } & \multirow{3}{*}{$\mathrm{N}$} & \multirow{3}{*}{$\%$} \\
\hline & \multicolumn{2}{|c|}{ Ao } & \multicolumn{2}{|c|}{$\mathrm{Am}$} & \multicolumn{2}{|c|}{$\mathrm{Ac}$} & \multicolumn{2}{|c|}{$\mathrm{Bt}$} & \multicolumn{2}{|c|}{$\mathrm{Da}$} & \multicolumn{2}{|c|}{ Il } & \multicolumn{2}{|c|}{$\mathrm{Pt}$} & \multicolumn{2}{|r|}{$\mathrm{Pg}$} & \multicolumn{2}{|c|}{$\mathrm{Sh}$} & & \\
\hline & $\mathrm{T}$ & $\mathrm{F}$ & $\mathrm{T}$ & $\bar{F}$ & $\mathrm{~T}$ & $\mathrm{~F}$ & $\mathrm{~T}$ & $\mathrm{~F}$ & $\mathrm{~T}$ & $\mathrm{~F}$ & $\mathrm{~T}$ & $\bar{F}$ & $\mathrm{~T}$ & $\mathrm{~F}$ & $\mathrm{~T}$ & $\mathrm{~F}$ & $\mathrm{~T}$ & $\mathrm{~F}$ & & \\
\hline \multicolumn{21}{|l|}{ Toxotrypanini } \\
\hline Anastrepha alveatoides Blanchard, 1961 & - & - & - & - & - & - & - & - & 1 & - & - & - & - & - & - & - & - & - & 1 & 0.04 \\
\hline Anastrepha castanea Norrbom, 1998 & - & - & - & - & - & - & - & - & - & - & - & - & - & - & - & - & - & $1 * * *$ & 1 & 0.04 \\
\hline Anastrepha daciformes Bezzi, 1909 & - & - & - & - & - & - & - & - & - & - & - & - & - & - & - & - & - & $3 * * *$ & 3 & 0.13 \\
\hline Anastrepha distincta Greene, 1934 & - & - & - & - & - & - & - & - & - & - & - & 2 & 1 & - & - & $1 * *$ & - & - & 4 & 0.17 \\
\hline Anastrepha fraterculus (Wiedemann, 1830) & - & - & - & - & - & - & - & - & - & - & - & - & 2 & - & 7 & 108 & - & - & 117 & 5.08 \\
\hline Anastrepha hamata Loew, 1873 & - & - & - & - & - & - & - & - & - & - & - & - & 6 & - & - & - & 1 & - & 7 & 0.30 \\
\hline Anastrepha leptozona Hendel, 1914 & - & - & 1 & - & - & - & 1 & - & 1 & - & - & - & 4 & 554 & - & - & - & - & 561 & 24.35 \\
\hline Anastrepha montei Lima, 1934 & - & - & - & - & 1 & - & - & - & - & - & - & - & - & - & - & - & - & - & 1 & 0.04 \\
\hline Anastrepha obliqua (Macquart, 1835) & - & - & 3 & - & 11 & 488 & - & - & - & - & - & - & - & - & 17 & 8 & - & - & 527 & 22.88 \\
\hline Anastrepha rheediae Stone, 1942 & - & - & - & - & - & - & 1 & - & - & - & - & - & - & - & - & - & 1 & - & 2 & 0.09 \\
\hline Anastrepha serpentina (Wiedemann, 1830) & - & - & - & - & - & - & - & - & - & - & - & - & - & 31 & - & - & - & - & 31 & 1.35 \\
\hline Anastrepha sororcula Zucchi, 1979 & 1 & - & 3 & - & 5 & 13 & 1 & - & - & - & 1 & - & - & - & 17 & 279 & - & - & 320 & 13.89 \\
\hline Anastrepha striata Schiner, 1868 & - & - & - & - & - & 5 & - & - & - & - & - & - & - & $4^{*}$ & 8 & 291 & - & - & 308 & 13.37 \\
\hline Anastrepha turpiniae Stone, 1942 & - & - & - & - & - & - & - & - & - & - & 2 & - & - & - & - & 66 & - & - & 68 & 2.95 \\
\hline Anastrepha zenildae Zucchi, 1979 & - & - & - & - & - & - & - & - & - & - & - & - & - & - & 1 & 7 & - & - & 8 & 0.35 \\
\hline Anastrepha zernyi Lima, 1934 & - & - & - & - & - & - & - & - & - & - & - & - & - & 2 & - & - & - & - & 2 & 0.09 \\
\hline Anastrepha sp.1 & - & - & - & - & - & - & - & - & - & - & - & - & - & 8 & - & - & - & - & 8 & 0.35 \\
\hline Anastrepha sp.2 & - & - & - & - & - & - & - & - & - & - & 2 & - & 1 & - & - & - & - & - & 3 & 0.13 \\
\hline \multicolumn{21}{|l|}{ Ceratitidini } \\
\hline Ceratitis capitata (Wiedemann, 1824) & - & - & 3 & - & 8 & 312 & - & - & - & - & - & - & - & - & 1 & 7 & - & - & 331 & 14.37 \\
\hline Total individuals & 1 & - & 10 & - & 25 & 818 & 3 & - & 2 & - & 5 & 2 & 14 & 599 & 51 & 767 & 2 & 4 & 2,303 & 100.00 \\
\hline Total species & 1 & - & 4 & - & 4 & 4 & 3 & - & 2 & - & 3 & 1 & 4 & 5 & 6 & 8 & 2 & 2 & 19 & \\
\hline
\end{tabular}

Table V. Abundance and relative percentage of fruit flies (Diptera, Tephritidae) obtained in unripe and ripe fruits from cultivated and wild fruit plants in the Cerrado-Pantanal ecotone, Aquidauana, Mato Grosso do Sul, Brazil (June 2009 to June 2011).

\begin{tabular}{|c|c|c|c|c|c|c|c|c|c|c|c|c|c|c|c|c|c|c|c|c|}
\hline \multirow{3}{*}{ Taxon } & \multicolumn{4}{|c|}{ Ac } & \multicolumn{4}{|c|}{ Il } & \multicolumn{4}{|c|}{$\mathrm{Pt}$} & \multicolumn{4}{|c|}{$\mathrm{Pg}$} & \multicolumn{4}{|c|}{$\mathrm{Sh}$} \\
\hline & \multicolumn{2}{|c|}{ Unripe } & \multicolumn{2}{|c|}{ Ripe } & \multicolumn{2}{|c|}{ Unripe } & \multicolumn{2}{|c|}{ Ripe } & \multicolumn{2}{|c|}{ Unripe } & \multicolumn{2}{|c|}{ Ripe } & \multicolumn{2}{|c|}{ Unripe } & \multicolumn{2}{|c|}{ Ripe } & \multicolumn{2}{|c|}{ Unripe } & \multicolumn{2}{|c|}{ Ripe } \\
\hline & $\mathrm{N}$ & $\%$ & $\mathrm{~N}$ & $\%$ & $\mathrm{~N}$ & $\%$ & $\mathrm{~N}$ & $\%$ & $\mathrm{~N}$ & $\%$ & $\mathrm{~N}$ & $\%$ & $\mathrm{~N}$ & $\%$ & $\mathrm{~N}$ & $\%$ & $\mathrm{~N}$ & $\%$ & $\mathrm{~N}$ & $\%$ \\
\hline \multicolumn{21}{|l|}{ Toxotrypanini } \\
\hline Anastrepha castanea & - & - & - & - & - & - & - & - & - & - & - & - & - & - & - & - & - & - & 1 & 25.00 \\
\hline Anastrepha daciformes & - & - & - & - & - & - & - & - & - & - & - & - & - & - & - & - & 1 & 25.00 & 2 & 50.00 \\
\hline Anastrepha distincta & - & - & - & - & - & - & 2 & 100.00 & - & - & - & - & - & - & 1 & 0.13 & - & - & - & - \\
\hline Anastrepha fraterculus & - & - & - & - & - & - & - & - & - & - & - & - & - & - & 108 & 14.03 & - & - & - & - \\
\hline Anastrepha leptozona & - & - & - & - & - & - & - & - & 49 & 8.18 & 505 & 84.31 & - & - & - & - & - & - & - & - \\
\hline Anastrepha obliqua & 9 & 1.10 & 479 & 58.56 & - & - & - & - & - & - & - & - & - & - & 8 & 1.04 & - & - & - & - \\
\hline Anastrepha serpentina & - & - & - & - & - & - & - & - & - & - & 31 & 5.17 & - & - & - & - & - & - & - & - \\
\hline Anastrepha sororcula & - & - & 13 & 1.59 & - & - & - & - & - & - & - & - & - & - & 279 & 36.38 & - & - & - & - \\
\hline Anastrepha striata & 1 & 0.12 & 4 & 0.49 & - & - & - & - & - & - & 4 & 0.67 & 64 & 8.34 & 227 & 29.60 & - & - & - & - \\
\hline Anastrepha turpiniae & - & - & - & - & - & - & - & - & - & - & - & - & - & - & 66 & 8.60 & - & - & - & - \\
\hline Anastrepha zenildae & - & - & - & - & - & - & - & - & - & - & - & - & - & - & 7 & 0.91 & - & - & - & - \\
\hline Anastrepha zernyi & - & - & - & - & - & - & - & - & 2 & 0.33 & - & - & - & - & - & - & - & - & - & - \\
\hline Anastrepha sp.1 & - & - & - & - & - & - & - & - & 8 & 1.34 & - & - & - & - & - & - & - & - & - & - \\
\hline \multicolumn{21}{|l|}{ Ceratitidini } \\
\hline Ceratitis capitata & 3 & 0.37 & 309 & 37.76 & - & - & - & - & - & - & - & - & - & - & 7 & 0.91 & - & - & - & - \\
\hline Total individuals & 13 & 1.59 & 805 & 98.41 & - & - & 2 & 100.00 & 59 & 9.85 & 540 & 90.15 & 64 & 8,34 & 703 & 91.66 & 1 & 25.00 & 3 & 75.00 \\
\hline Total species & & 3 & & 4 & & & & 1 & & 3 & & 3 & & 1 & & 8 & & 1 & & 2 \\
\hline
\end{tabular}

Ac - Averrhoa carambola; Il - Inga laurina; $\mathrm{Pt}$ - Pouteria torta; $\mathrm{Pg}$ - Psidium guajava and Sh - Schoepfia $\mathrm{sp}$.

and February 2011 (Fig. 1). In P. guajava this species was obtained from December 2010 to February 2011.

Larvae of $A$. striata obtained from fruits of $P$. guajava were recovered from August to December 2009, with a popu- lation peak in November, occurring during eight months of 2010 and five in 2011 (Fig. 2). These larvae were also obtained in November and December of 2010 infesting $P$. torta fruits and in March, April and June of 2011 in A. carambola. 
Anastrepha sororcula obtained from larvae infesting fruits of $P$. guajava presented a population peek in January 2010 (Fig. 2) and occurred in March, April and June of 2011 in A. carambola fruits.

A total of 215 parasitoids were recovered from the families Braconidae (96.74\%) and Pteromalidae (3.26\%). Braconidae were represented by Doryctobracon areolatus (Szépligeti, 1911), Utetes anastrephae Viereck, 1913 and Opius bellus Gahan, 1930, while Pteromalidae was represented by an unidentified species (Table VI).

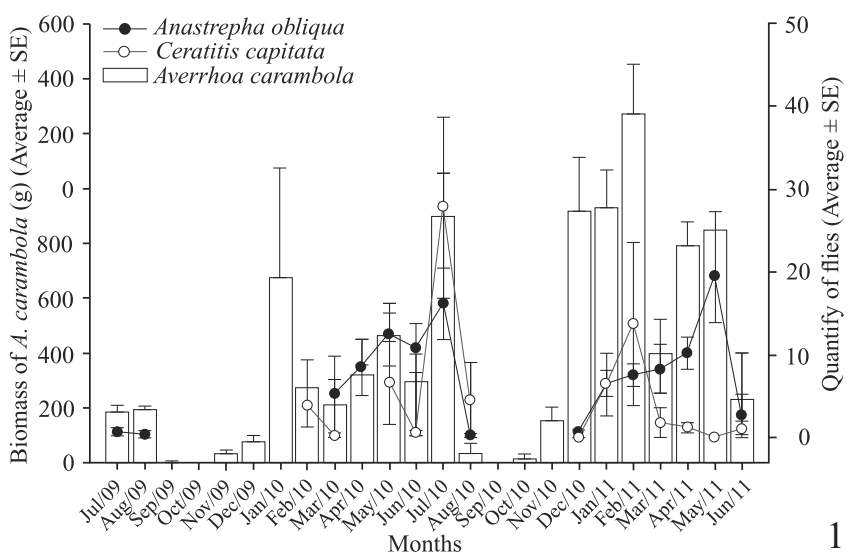

Parasitism of larvae in A. carambola fruit was $5.88 \%$ in $2009,5.61 \%$ in 2010 and $2.07 \%$ in 2011 . In P. guajava it was $3.73 \%$ in $2009,0.71 \%$ in 2010 and $4.42 \%$ in 2011 . In P. torta, parasitism of $1.48 \%$ was observed in 2010 (Table VI). Most parasitoids were acquired from larvae infesting mature fruits, except one specimen of $D$. areolatus that parasitized larvae infesting unripe fruit of $A$. carambola.

Doryctobracon areolatus was the most abundant (82.79\%) and generalist among the parasitoids obtained, parasitizing larvae acquired from A. carambola, $P$. guajava and

Figs. 1-2. Population fluctuation of larvae of Ceratitis capitata, Anastrepha obliqua and fruit biomass of Averrhoa carambola (1), and Anastrepha sororcula, Anastrepha striata and fruit biomass of Psidium guajava (2) in the Cerrado-Pantanal ecotone, Aquidauna, Mato Grosso do Sul, Brazil, from July 2009 to June 2011 .

Table VI. Total number (N) of Tephritidae larvae (Diptera, Tephritoidea), parasitoids and parasitism percentage, in fruits of Averrhoa carambola, Psidium guajava and Pouteria torta, collected in the Cerrado-Pantanal ecotone, Aquidauana, Mato Grosso do Sul, Brazil (June 2009 to June 2011).

\begin{tabular}{|c|c|c|c|c|c|c|c|c|c|c|c|c|c|c|c|c|c|c|c|c|c|c|c|c|c|c|}
\hline \multirow[t]{2}{*}{ Variables evalauted } & \multicolumn{7}{|c|}{2009} & \multicolumn{12}{|c|}{2010} & \multicolumn{6}{|c|}{2011} & \multirow[t]{2}{*}{$\mathrm{N}$} \\
\hline & Jun & Jul & Aug & Sep & Oct & Nov & Dec & Jan & Feb & Mar & Apr & May & Jun & Jul & Aug & Sep & Oct & Nov & Dec & Jan & Feb & Mar & Apr & May & Jun & \\
\hline \multicolumn{27}{|l|}{ Averrhoa carambola } \\
\hline Tephritidae & 6 & 8 & 2 & - & - & 1 & - & - & 30 & 72 & 140 & 220 & 140 & 536 & 47 & - & - & - & 9 & 263 & 297 & 101 & 242 & 221 & 37 & 2372 \\
\hline \multicolumn{27}{|l|}{ Braconidae } \\
\hline $\begin{array}{l}\text { Doryctobracon areolatus } \\
\text { (Szépligeti, 1911) }\end{array}$ & - & - & - & - & - & 1 & - & - & - & 14 & 12 & 12 & 5 & 7 & 1 & - & - & - & - & - & 2 & 2 & 14 & 1 & - & 71 \\
\hline Parasitism (\%) & - & - & - & - & - & 100 & - & - & - & 19.44 & 8.57 & 5.45 & 3.57 & 1.31 & 2.13 & - & - & - & - & - & 0.67 & 1.98 & 5.79 & 0.45 & - & - \\
\hline $\begin{array}{l}\text { Utetes anastrephae } \\
\text { Viereck, } 1913\end{array}$ & - & - & - & - & - & - & - & - & - & - & 4 & 3 & 1 & 1 & - & - & - & - & - & - & 3 & - & 1 & - & - & 13 \\
\hline Parasitism (\%) & - & - & - & - & - & - & - & - & - & - & 2.86 & 1.36 & 0.71 & 0.19 & - & - & - & - & - & - & 1.01 & - & 0.41 & - & - & - \\
\hline $\begin{array}{l}\text { Opius bellus Gahan, } \\
1930\end{array}$ & - & - & - & - & - & - & - & - & - & - & - & - & - & - & - & - & - & - & - & - & 1 & - & - & - & - & 1 \\
\hline Parasitism (\%) & - & - & - & - & - & - & - & - & - & - & - & - & - & - & - & - & - & - & - & - & 0.34 & - & - & - & - & - \\
\hline \multicolumn{27}{|l|}{ Pteromalidae } \\
\hline Pteromalidae sp. 1 & - & - & - & - & - & - & - & - & - & - & - & - & - & 7 & - & - & - & - & - & - & - & - & - & - & - & 7 \\
\hline Parasitism (\%) & - & - & - & - & - & - & - & - & - & - & - & - & - & 1.31 & - & - & - & - & - & - & - & - & - & - & - & - \\
\hline \multicolumn{27}{|l|}{ Psidium guajava } \\
\hline Tephritidae & - & - & 7 & 43 & 87 & 659 & 412 & 35 & 10 & 14 & - & - & - & 27 & 21 & 36 & 47 & 63 & 27 & 749 & 307 & 68 & 32 & 5 & 62 & 2711 \\
\hline \multicolumn{27}{|l|}{ Braconidae } \\
\hline Doryctobracon areolatus & - & - & - & - & - & 17 & 14 & - & - & - & - & - & - & - & - & - & - & 2 & - & 42 & 10 & - & - & - & - & 85 \\
\hline Parasitism (\%) & - & - & - & - & - & 2.58 & 3.40 & - & - & - & - & - & - & - & - & - & - & 3.17 & - & 5.61 & 3.26 & - & - & - & - & - \\
\hline Utetes anastrephae & - & - & - & - & - & 14 & - & - & - & - & - & - & - & - & - & - & - & - & - & 2 & - & - & - & - & - & 16 \\
\hline Parasitism (\%) & - & - & - & - & - & 2.12 & - & - & - & - & - & - & - & - & - & - & - & - & - & 0.27 & - & - & - & - & - & - \\
\hline \multicolumn{27}{|l|}{ Pouteria torta } \\
\hline Tephritidae & - & - & - & - & - & 44 & 28 & 10 & - & - & - & - & - & - & 1 & - & 270 & 1057 & 225 & - & - & - & - & - & - & 1635 \\
\hline \multicolumn{27}{|l|}{ Braconidae } \\
\hline Doryctobracon areolatus & - & - & - & - & - & - & - & - & - & - & - & - & - & - & - & - & 2 & 17 & 3 & - & - & - & - & - & - & 22 \\
\hline Parasitism (\%) & - & - & - & - & - & - & - & - & - & - & - & - & - & - & - & - & 0.74 & 1.60 & 1.33 & - & - & - & - & - & - & - \\
\hline
\end{tabular}


$P$. torta. The parasitism percentage per insect in larvae obtained from A. carambola was $2.99 \%, 3.14 \%$ in $P$. guajava and $1.35 \%$ in $P$. torta. This parasitoid was recovered in November and December of 2009, from March to August and October to December of 2010 and from January to May of 2011, most expressively in March 2010 when the parasitism percentage of larvae obtained from $A$. carambola was $19.44 \%$ (Table VI).

Utetes anastrephae was the second most abundant species parasitizing larvae from P. guajava and A. carambola, while Opius bellus and Pteromalidae sp.1 were associated only with tephritid larvae in $A$. carambola (Table VI).

\section{DISCUSSION}

The higher number of tephritids obtained from fruits compared to that from traps was probably due to the greater attractiveness of the fruit, since the fruit flies utilized them to reproduce, whereas the bait used in the traps is only a food source for the adults. Another factor that may imply an increased abundance in fruits may be related to the features of each sampling method, since in the fruits one or more females may oviposit at each visit, and a female has the ability to oviposit over 200 eggs during her life in different periods and fruits, in the trap, when captured, each fly is sampled once. The attraction of females to the fruit is enhanced by color and by the release of volatiles, as highlighted by Malo et al. (2005) and Zarbin et al. (2009).

Montes et al. (2011) obtained a 1:2 sex ratio (Q:: $\left.0^{\prime \prime}\right)$ in areas with cucurbits, as in this study, however it appears that there is no common standard with regards to the sex ratio of tephritids captured in traps baited with proteins, as verified by various authors who obtained a higher number of females (Montes \& Raga 2006; Dutra et al. 2009; Trindade \& Uchôa 2011; Santos et al. 2011). The variation of the number of males and females in the traps may likely be related to the number of samples of each sex in the field or that females are feeding and copulating in areas near the trap and then moving towards the oviposition sites.

The fact that frugivorous fruit flies developing in unripe fruits of P. torta, P. guajava and Shoepfia sp. had greater viability than in mature fruits can be explained by the lower number of larvae obtained from unripe fruits. However, this demonstrates that although unripe fruits were not preferred for oviposition, they allowed for successful reproduction of the species.

Pereira-Rêgo et al. (2011) obtained larvae of $A$. fraterculus from unripe, semiripe and ripe fruits of Psidium cattleyanum var. lucidum (Mart. ex O. Berg) Kiaersk. (araçá-amarelo), P. cattleyanum (Mart. ex O. Berg) Kiaersk. (araçá-vermelho) and $P$. guajava. These larvae transformed into adults similar in relation to pupal weight and wing area within each botanical species, independent of the stage of ripeness. Carvalho et al. (1998), in studies of the biology of Anastrepha obliqua (Macquart, 1835), confirmed that peak oviposition is attained during the reproduction period. In the present study, the in- festation of unripe fruit may also be due to concurrence with the peak of oviposition of this species during this maturation state. The ability to infest unripe fruits by some fruit fly species is a fact that may contribute to their predominance in some hosts. Moura \& Moura (2006) confirmed that $C$. capitata was the only dominant and constant species in guava fruits and reported that this association may be due to the fact that it is the only species that fully infested the fruits.

The high tephritid infestation confirmed in the present study in fruits of $P$. guajava and $A$. carambola, was different than that observed by Sá et al. (2008) in the fruit production center in Anagé, Bahia, Brazil, where fruits of A carambola were not attacked and infestation in P. guajava was reduced, which reinforces the need for regional studies.

Anastrepha alveatoides Blanchard, 1961 occurred only in the trap installed in D. alata, indicating that a specimen of sea lemon (Ximenia americana L.), its only reported host in Pantanal, Brazil (Uchôa \& Nicácio 2010), is likely near the plant of D. alata. The infestation of Shoepfia sp. fruits by Anastrepha castanea Norrbom, 1998 and A. daciformes Bezzi, 1909 constitutes the first record for this host. However, these fly species are not the only ones who use it for oviposition, since Uchôa and Nicácio (2010) reported infestations by $A$. macrura, A. sororcula and A. zernyi in fruits of this species in the same region.

The presence of Anastrepha distincta Greene, 1934 in the study area, captured in the trap installed in P. torta and in ripe fruits of I. laurina and $P$. guajava was also observed by Uchôa and Nicácio (2010) in association with fruits of $I$. laurina in the same region. The association of this fly with fruits of P. guajava in the state of Mato Grosso do Sul, however, has not been reported before.

Although Anastrepha fraterculus (Wiedemann, 1830) was obtained in traps installed in $P$. torta and $P$. guajava, this species infest only fruits of Myrtaceae. In the state of São Paulo, Raga et al. (2005) found that this species is dominant in fruits of $P$. guajava.

Anastrepha hamata (Loew, 1873) was obtained in traps installed in P. torta and Shoepfia sp., not occurring in any fruit of the surveyed plants. According to Zucchi (2000a), the host of this tephritid species is unknown. The association of Anastrepha leptozona Hendel, 1914 with fruits of P. torta was also verified by Uchôa and Nicácio (2010) who conducted studies in the Pantanal region of Mato Grosso do Sul.

The capture of Anastrepha montei Lima, 1934 in the trap installed in $A$. carambola may be due to the abundant regional production of Manihot esculenta Crantz, which according to Zucchi et al. (2000a) is a host of this fly species.

Predominance of Anastrepha obliqua in A. carambola fruits was also observed by Souza-Filho et al. (2000) and Uramoto et al. (2004) in the state of São Paulo. Occurrence of Anastrepha serpentina (Wiedemann, 1830) in fruits of $P$. torta seems common in the region, since it was also verified by Uchôa and Nicácio (2010).

The presence of Anastrepha sororcula Zucchi, 1979 in more than one-half of the installed traps was due to the fact 
that $P$ guajava is common in the region and also resultant of the existence of an orchard of this fruit plant in the experimental unit of the UEMS Fruticulture. This tephritid is the main species infesting guava fruits in Mato Grosso do Sul (Uchôa \& Nicácio 2010).

Anastrepha striata Schiner, 1868 infesting P. torta is the first report of the association between this fly species with fruits of Sapotaceae. Anastrepha turpiniae Stone, 1942 was obtained in the trap installed in I. laurina and also recovered from ripe fruits of P. guajava. Also verified was the presence of Anastrepha zenildae Zucchi, 1979 associated with ripe fruit of this Myrtaceae.

Anastrepha zernyi Lima, 1934 and Anastrepha sp.1 were sampled in unripe fruits of $P$. torta, however they were not captured in the trap installed in this fruit plant. Anastrepha sp. 2 was obtained in the traps installed in I. laurina and $P$. torta, but was not associated with any fruit plant studied.

Ceratitis capitata (Wiedemann, 1824) was associated with the traps installed in A. muricata, A. carambola and P. guajava, however it was obtained only from fruit of the last two plants. The Mediterranean fruit fly was recovered from unripe and ripe fruits of $A$. carambola, but in P. guajava it occurred only in ripe fruits.

The absence of tephritid attack in $A$. muricata, $C$. sinensis and $D$. alata, and the low infestation in $A$. occidentale may possibly be explained by the fact that these flies are not adapted to colonize some fruits, as noted by Branco et al. (2000). Similar results were obtained by Souza et al. (2008) who found no infestations in fruits of $A$. muricata, $C$. sinensis and $A$. occidentale, and by Alvarenga et al. (2009), Pereira et al. (2010) and Silva et al. (2011) who also did not find any fruit fly specimens in fruits of $A$. muricata.

The temporal overlap of fruit production by different plant species may permit the maintenance of pest species populations (Ronchi-Teles \& Silva 2005). However, the presence of native fruit species may be an alternative for the natural control of tephritids, since larvae of the fruit fly species that infest their fruits are reservoirs of Anastrepha parasitoids (López et al. 1999; Carvalho et al. 2010).

Fruit flies emerging from fruits infested with larvae occurred during the majority of the experimental period, possibly due to alternating hosts and the overlapping phenology of the fruit plant species sampled. Anastrepha obliqua, A. sororcula, A. striata and C. capitata were common throughout the study period while the other species occurred during isolated months. The population peaks of these four fly species were directly associated with the period of highest fruit production (Figs. 1 and 2). According to Ronchi-Teles \& Silva (2005) the availability of the host is important for population fluctuation and abiotic factors only have little influence on these flies.

Parasitism of larvae of Tephritidae by Braconidae observed in this study was found in the same region by Nicácio et al. (2011) and is common in Brazil (Silva et al. 2007a; Souza-Filho et al. 2007; Leal et al. 2009; Ronchi-Teles et al. 2011). Doryctobracon areolatus is considered an important native species, mainly parasitizing species of Anastrepha in neotropical countries (Uchôa-Fernandes et al. 2003a; Uchôa 2012). Due to the frequency, abundance and capacity to parasitize fruit fly larvae in native and exotic fruits, this parasitoid species shows promise for integration in biological control programs of fruit flies in agroecosystems (Nunes et al 2011; Uchôa 2012). The low abundance of $U$. anastrephae and Opius bellus is common in other studies conducted in Brazil (Uchôa-Fernandes et al. 2003a; Lima Junior et al. 2007; Costa et al. 2009).

The dominance of $D$. areolatus is possibly related to the length of the ovipositor which permits reaching larvae in various hosts. Parasitoids with long ovipositors parasitize larvae in large and small fruit, but those with short ovipositor are limited to parasitism of larvae in small fruits (López et al. 1999; Sivinski et al. 1997, 2001; Ovruski et al. 2008). The higher parasitism incidence of fly larvae in ripe fruit implies possible susceptibility of these larvae during this period, since in this stage the fruits probably release a larger amount of volatiles and their pulp is softer, facilitating parasitism (Guimarães \& Zucchi 2004; Silva et al. 2007b).

\section{ACKNOWLEDGEMENTS}

To the Coordenação de Aperfeiçoamento de Pessoal de Nivel Superior (CAPES) for providing the scholarship to the first author, to Jorge Adriano de Deus Ricardo (UEMS) for his assistance in the execution of this work and MSc. Anderson Puker (Federal University of Viçosa) for his suggestions.

\section{REFERENCES}

Alvarenga, C.D.; Matrangolo, C.A.R.; Lopes, G.N.; Silva, M.A.; Lopes, E.N.; Alves, D.A.; Nascimento, A.S. \& Zucchi, R.A. 2009. Moscasdas-frutas (Diptera: Tephritidae) e seus parasitóides em plantas hospedeiras de três municípios do norte do estado de Minas Gerais. Arquivos do Instituto Biológico 76: 195-204.

Branco, E.S, Vendramim, J.D. \& Denardi, F. 2000. Resistência às moscasdas-frutas em fruteiras, p.161-167. In: Malavasi, A. \& Zucchi, R.A. (eds.). Moscas-das-frutas de importância econômica no Brasil: Conhecimento básico e aplicado. Ribeirão Preto, Holos, 327 p.

Canesin, A. \& Uchôa-Fernandes, M.A. 2007. Análise faunística e flutuação populacional de moscas-das-frutas (Diptera, Tephritidae) em um fragmento de floresta semidecídua em Dourados, Mato Grosso do Sul, Brasil. Revista Brasileira de Zoologia 24: 185-190.

Carvalho, R.S., Nascimento, A.S. \& Fernandes, Ê.B. 1998. Dados biológicos de Anastrepha obliqua Macquart (Diptera:Tephritidae) em Manga. Anais da Sociedade Entomológica do Brasil 27: 469-472.

Carvalho, R.S., Soares Filho, W.S. \& Ritzinger, R. 2010. Umbu-cajá como repositório natural de parasitóide nativo de moscas-das-frutas. Pesquisa Agropecuária Brasileira 45: 1222-1225.

Costa, S.G.M., Querino, R.B., Ronchi-Teles, B., Penteado-Dias, A.M.M. \& Zucchi, R.A. 2009. Parasitoid diversity (Hymenoptera: Braconidae and Figitidae) on frugivorous larvae (Diptera: Tephritidae and Lonchaeidae) at Adolpho Ducke Forest Reserve, central Amazon region, Manaus, Brazil. Brazilian Journal of Biology 69: 363-370.

Dutra, V.S., Santos, M. S., Souza Filho, Z.A., Araujo, E.L. \& Silva, J.G. 2009. Faunistic analysis of Anastrepha spp. (Diptera: Tephritidae) on a guava orchard under organic management in the municipality of Una, Bahia, Brazil. Neotropical Entomology 38: 133-138. 
Evstigneev, D.A. 2011. The fruit flies of the tribe Myopitini (Diptera: Tephritidae) of Ulyanovsk Region (Russia). Ukrainska Entomofaunistyka 2: 21-30.

FAO. 2009. Review of the world market situation for bananas and tropical fruits. Available at: ftp://ftp.fao.org/docrep/fao/meeting/018/ k6854e.pdf (accessed 3 November 2011).

Felix, C.S.; Uchôa-Fernandes, M.A. \& Faccenda, O. 2009. Capture of Anastrepha sororcula (Diptera: Tephritidae) in McPhail and Jackson traps with food attractant and virgin adults. Brazilian Archives of Biology and Technology 52: 99-104.

Garcia, F.R.M. \& Norrbom, A.L. 2011. Tephritoid flies (Diptera, Tephritoidea) and their plant hosts from the state of Santa Catarina in southern Brazil. Florida Entomologist 94: 151-157.

Gonçalves, G.B., Santos, J.C.G., Silva, C.E., Santos, E.S.S., Nascimento, R.R., Sant'Ana, A.E. G. \& Zucchi, R.A. 2006. Occurrence of fruit flies (Diptera: Tephritidae) in the state of Alagoas, Brazil. Florida Entomologist 89: 93-94.

Guimarães, J.A. \& Zucchi, R.A. 2004. Parasitism behavior of three species of Eucoilinae (Hymenoptera: Cynipoidea: Figitidae) fruit fly parasitoids (Diptera) in Brazil. Neotropical Entomology 33: 217-224.

INCT. 2009. Frutos tropicais. Available at: http://www.frutostropicais.com.br/ AReport_INCTFT_2009.pdf (accessed 06 October 2011).

Jemâa, J.M.B., Bachrouch, O., Allimi, E. \& Dhouibi, M.H. 2010. Field evaluation of Mediterranean fruit fly mass trapping with Tripack $^{\circledR}$ as alternative to malathion bait-spraying in citrus orchards. Spanish Journal of Agricultural Research 8: 400-408.

Khaghaninia, S., Zarghani, E., Namin, S.M. \& Korneyev, V.A. 2011. A new species of Tephritis Latreille (Diptera: Tephritidae) with an unusual wing pattern from Iran and its taxonomic implications. Zootaxa 3047: 54-62.

Leal, M.R., Souza, S.A.S., Aguiar-Menezes, E., Lima Filho, M. \& Menezes, E.B. 2009. Diversidade de moscas-das-frutas, suas plantas hospedeiras e seus parasitóides nas regiões Norte e Noroeste do estado do Rio de Janeiro, Brasil. Ciência Rural 39: 627-634.

Lima Junior, C.A., Santos, W.S. \& Carvalho, C.A.L. 2007. Moscas-dasfrutas (Diptera: Tephritidae) associadas ao Umbu-Cajá (Anacardiaceae) no Vale do Rio Paraguaçu, Bahia, Brasil. Revista Brasileira de Agrociência 13: 399-402.

López, M., Aluja, M. \& Sivinski, J. 1999. Hymenopterous larval-pupal and pupal parasitoids of Anastrepha flies (Diptera: Tephritidae) in Mexico. Biological Control 15: 119-129.

Malo, E.A., Cruz-López, L., Toledo, J., Del Mazo, A., Virgen, A. \& Rojas, J.C. 2005. Behavioral and electrophysiological responses of the Mexican fruit fly (Diptera: Tephritidae) to guava volatiles. Florida Entomologist 88: $364-371$.

Montes, S.M.N.M. \& Raga, A. 2006. Eficácia de atrativos para monitoramento de Ceratitis capitata (Diptera: Tephritidae) em pomar de citros. Arquivos do Instituto Biológico 73: 317-323.

Montes, S.M.N.M., Raga, A. \& Souza-Filho, M.F. 2011. Levantamento de espécies de Anastrepha (Diptera: Tephritidae) em áreas de cucurbitáceas sob sistema de mitigação de risco. Arquivos do Instituto Biológico 78: 317-320.

Moura, A.P. \& Moura, D.C.M. 2006. Espécies de moscas-das-frutas (Diptera: Tephritidae) associadas à cultura da goiabeira (Psidium guajava Linnaeus) em Fortaleza, Ceará. Arquivos do Instituto Biológico 73: 65-71.

Nicácio, J.N., Uchôa, M.A., Faccenda, O., Guimarães, J.A. \& Marinho, C.F. 2011. Native larval parasitoids (Hymenoptera) of frugivorous Tephritoidea (Diptera) in South Pantanal region, Brazil. Florida Entomologist 94: 407-419.

Nicácio, J. \& Uchôa, M.A. 2011. Diversity of frugivorous flies (Diptera: Tephritidae and Lonchaeidae) and their relationship with host plants (Angiospermae) in environments of South Pantanal region, Brazil. Florida Entomologist 94: 443-466.

Nunes, A.M., Nava, D.E., Müller, F.A., Gonçalves, R.S. \& Garcia, M.S. 2011. Biology and parasitic potential of Doryctobraconareolatus on Anastrephafraterculus larvae. Pesquisa Agropecuária Brasleira 46: 669-671.
Ovruski, S.M., Schliserman, P., Oroño, L.E., Nuñéz-Campero, S.R., AlbornozMedina, P., Bezdjian, L.P. \& Nieuwenhove, G.A.V. 2008. Natural ocurrence of hymenopterous parasitoids associated with Anastrepha fraterculus (Diptera: Tephritidae) in Myrtaceae species in Entre Rios, northeastern Argentina. Florida Entomologist 91: 220-228.

Paranhos, B.A.J., Walder, J.M.M. \& Alvarenga, C.D. 2007. Parasitismo de larvas da mosca-do-mediterrâneo por Diachasmimorpha longicaudata (Ashmead) (Hymenoptera: Braconidae) em diferentes cultivares de goiaba. Neotropical Entomology 36: 243-246.

Pereira, J.D.B., Buriti, D. P., Lemos, W.P., Silva, W.R. \& Silva, R.A. 2010. Espécies de Anastrepha Schiner (Diptera: Tephritidae), seus hospedeiros e parasitóides nos estados do Acre e Rondônia, Brasil. Biota Neotropica 10: 441-446.

Pereira-Rêgo, D.R.G., Jahnke, S.M., Redaelli, L.R. \& Schaffer, N. 2011. Morfometria de Anastrepha fraterculus (Wied) (Diptera: Tephritidae) relacionada a hospedeiros nativos, Myrtaceae. Arquivos do Instituto Biológico 78: 37-43.

Raga, A., Machado, R.A., Souza Filho, M.F., Sato, M.E. \& Siloto, R.C. 2005. Tephritoidea (Diptera) species from Myrtaceae fruits in the State of São Paulo, Brazil. Entomotropica 20: 11-14.

Rodrigues, S.R., Nantes, L.R., Souza, S.R., Abot, A.R. \& Uchôa-Fernandes, M.A. 2006. Moscas frugívoras (Diptera, Tephritoidea) coletadas em Aquidauana, MS. Revista Brasileira de Entomologia 50: 131-134.

Ronchi-Teles, B. \& Silva, N.M. 2005. Flutuação populacional de espécies de Anastrepha Schiner (Diptera: Tephritidae) na região de Manaus. Neotropical Entomology 34: 733-741.

Ronchi-Teles, B., Dutra, V.S., Costa, A.P.T., Aguiar-Menezes, E.L., Mesquita, A.C.A. \& Silva, J.G. 2011. Natural host plants and native parasitoids associated with Anastrepha pulchra and other Anastrepha species (Diptera: Tephritidae) in Central Amazon, Brazil. Florida Entomologist 94: $347-349$

Rousse, P., Duyck, P.F., Quilici, S. \& Ryckewaert, P. 2005. Adjustment of field cage methodology for testing food attractants for fruit flies (Diptera: Tephritidae). Annals of the Entomological Society of America 98: 402-408

Sá, R.F., Castellani, M.A., Nascimento, A.S., Brandão, M.H.S.T., Silva, A.N. \& Pérez-Maluf, R. 2008. Índice de infestação e diversidade de moscas-das-frutas em hospedeiros exóticos e nativos no pólo de fruticultura de Anagé, BA. Bragantia 67: 401-411.

Sabedot-Bordin, S.M., Bogus, G.M., Bampi, D. \& Garcia, F.R.M. Garcia. 2011. Tefritídeos endófagos (Diptera: Tephritidae) associados à Asteraceae em Chapecó, Santa Catarina. Biotemas 24: 15-20.

Santos, M.S., Navack, K.I., Araújo, E.L. \& Silva, J.G. 2011. Análise faunística e flutuação populacional de moscas-das-frutas (Diptera: Tephritidae) em Belmonte, Bahia. Revista Caatinga 24: 86-93.

Silva, R.A., Nascimento, D.B., Deus, E.G., Souza, G.D. \& Oliveira, L.P.S Oliveira. 2007a. Hospedeiros e parasitóides de Anastrepha spp. (Diptera: Tephritidae) in Itaubal do Piririm, estado do Amapá, Brasil. Ciência Rural 37: 557-560.

Silva, J. W. P.; J. M. S. Bento \& Zucchi R. A. 2007b. Olfactory response of three parasitoid species (Hymenoptera: Braconidae) to volatiles of guavas infested or not with fruit fly larvae (Diptera: Tephritidae). Biological Control 41: 304-311.

Silva, R.A., Lima, A.L., Xavier, S.L.O., Silva, W.R., Marinho, C.F. \& Zucchi, R.A. 2011. Espécies de Anastrepha (Diptera: Tephritidae), seus hospedeiros e parasitóides no sul do estado do Amapá, Brasil. Biota Neotropica 11: 431-436.

Sivinski J.; M. Aluja \& M. Lopéz.1997.Spatial and temporal distribution of parasitoids of Mexican Anastrepha species (Diptera: Tephritidae) within the canopies of fruit trees. Annals of the Entomological Society of America 90: 604-618.

Sivinski, J.; Aluja, M. \& Lopéz, M. 2001. Ovipositor length in a guild of parasitoids (Hymenoptera: Braconidae) attacking Anastrepha spp. fruit flies (Diptera: Tephritidae) in southern Mexico. Annals of the Entomological Society of America 94: 886-895.

Souza Filho, M.F., Raga, A. \& Zucchi, R.A. 2000. Incidencia de Anastrepha obliqua (Macquart) y Ceratitis capitata (Wiedemann) (Diptera: 
Tephritidae) en carambola (Averrhoa carambola L.) em ocho localidades del Estado de São Paulo, Brasil. Anais da Sociedade Entomológica do Brasil 29: 367-371.

Souza-Filho, Z.A.; Araujo, E.L.; Guimarães, J.A. \& Silva, J.G. 2007. Endemic parasitoids associated with Anastrepha spp. (Diptera: Tephritidae) infesting guava (Psidium guava) in southern Bahia, Brazil. Florida Entomologist 90: 783-785.

Souza, A.J.B., Lima, M.G.A., Guimarães, J.A. \& Figueiredo, A.E.Q. 2008. Moscas-das-frutas (Diptera: Tephritidae) associadas às plantas hospedeiras do pomar do campus do Pici da Universidade Federal do Ceará. Arquivos do Instituto Biológico 75: 2-27.

Trindade, R.B.R.\& Uchôa, M.A. 2011. Species of fruit flies (Diptera: Tephritidae) in a transect of the Amazonian Rainforest in Oiapoque, Amapá, Brazil. Zoologia 28: 653-657.

Uchôa-Fernandes, M.A. \& Zucchi, R.A. 1999. Metodologia de colecta de Tephritidae y Lonchaeidae frugívoros (Diptera, Tephritoidea) y sus parasitoides (Hymenoptera). Anais da Sociedade Entomológica do Brasil 28: 601-610.

Uchôa-Fernandes, M. A., Oliveira, I., Molina, R.M.S.\& Zucchi, R.A. 2002. Species diversity of frugivorous flies (Diptera: Tephritoidea) from hosts in the Cerrado of the state of MatoGrosso do Sul, Brazil. Neotropical Entomology 31: 515-524.

Uchôa-Fernandes, M.A., Molina, R.M. S., Oliveira, I., Zucchi, R.A., Canal, N.A. \& Díaz, N.B. 2003a. Larval endoparasitoids (Hymenoptera) of frugivorous flies (Diptera, Tephritoidea) reared from fruits of the cerrado of the State of Mato Grosso do Sul, Brazil. Revista Brasileira de Entomologia 47: 181-186.

Uchôa-Fernandes, M. A., Oliveira, I., Molina, R.M.S. \& Zucchi, R.A 2003b. Biodiversity of frugivorous flies (Diptera: Tephritoidea) captured in citrus groves, Mato Grosso do Sul, Brazil. Neotropical Entomology 32: 239-246.

Uchôa, M.A. \& Nicácio, J. 2010. New records of Neotropical fruit flies (Tephritidae), lance flies (Lonchaeidae) (Diptera: Tephritoidea), and their host plants in the South Pantanal and adjacent areas, Brazil. Annals of the Entomological Society of America 103: 723-733.

Uchôa, M.A. 2012. Fruit Flies (Diptera: Tephritoidea): Biology, Host Plants, Natural Enemies, and the Implications to Their Natural Control, p. 217-300. In: Larramendy, M.L. \& Soloneski, S. (ed.). Integrated Pest Management and Pest Control - Current and Future Tactics. Rijeka, InTech. DOI: 10.5772/31613

Uramoto, K., Walder, J.M.M. \& Zucchi, R.A. 2004. Biodiversidade de moscas-das-frutas do gênero Anastrepha (Diptera, Tephritidae) no campus da ESALQ-USP, Piracicaba, São Paulo. Revista Brasileira de Entomologia 48: 409-414.

Zarbin, P.H.G.; Rodrigues, M.A.C.M. \& Lima, E.R. 2009. Feromônios de insetos: tecnologia e desafios para uma agricultura competitiva no Brasil. Química Nova 32: 722-731.

Zucchi, R. A. 2000a. Espécies de Anastrepha, sinonímias, plantas hospedeiras e parasitóides, p. 41-48. In: Malavasi, A. \& Zucchi, R.A. (eds.). Moscas-das-frutas de Importância Econômica no Brasil. Ribeirão Preto, Holos, 327 p.

Zucchi, R. A. 2000b. Taxonomia, p. 13-24. In: Malavasi, A. \& Zucchi, R.A. (eds.). Moscas-das-frutas de Importância Econômica no Brasil. Ribeirão Preto, Holos, 327 p.

Zucchi, R. A. 2007. Diversidad, distribuición y hospederos del género Anastrepha en Brasil, p. 77-100. In: Hernández-Ortiz, V. (ed.). Moscas de la Fruta em Latinoamérica (Diptera: Tephritidae): Diversidad, Biología y Manejo. Distrito Federal, S y G Editores, 167 p. 